\title{
CAN WE LIVE WITHOUT THE INTERNET? AN OVERALL AND DEMOGRAPHIC ANALYSIS OF INTERNET USAGE AND DEPENDENCE
}

\author{
Alan R. Peslak, Penn State University, arp14@psu.edu
}

\begin{abstract}
We all seem to be addicted to the Internet. We all see people walking, driving, dining, and socializing while surfing their smartphone. But how strong is this dependence? In this analysis of Pew Internet Research data, we review the relative strength of this dependence, and we explore how it varies by age, sex, gender, and race.
\end{abstract}

Keywords: Internet, Internet Addiction, Internet Dependence, Gender, Race, Age, Internet Usage

\section{INTRODUCTION}

The Internet has become a powerful force in our society. Being online is perhaps the number one leisurely activity in the US today. According to Internet World Stats [13], 88\% of North America is online. This compares to US census reports that show that only $48 \%$ of Americans dine out as leisure activity and only $38 \%$ of Americans entertained friends or family at home both over the last 12 month. [20]. (These two leisure activities are the highest ranking leisure activities in the census report.) We all seem to be addicted to the Internet. We all see people walking, driving, dining, and socializing while surfing their smartphone. But how strong is this dependence? Is the dependence an addiction? Is it something that now that we are hooked, we can give up? There have been many studies which have begun to examine this dependency. In this analysis of Pew Internet Research data, we review the relative strength of Internet dependence and we explore how it varies by age, sex, gender, and race. It is important to understand the extent of Internet dependence. Some have seen Internet addiction as a disorder and others see may see an overreliance on external knowledge to the sacrifice of learned knowledge. Either way, an exploration of the extent of this dependence is warranted.

\section{RESEARCH METHODOLOGY}

Our research centered upon the following research questions: Can we live without the Internet? What is the extent of Internet usage and dependence and how does it vary by demographic variables in the US.

The research hypotheses to be tested are as follows:

$\mathrm{H}_{1}$ : Internet dependence as measured by difficulty of giving up the Internet exists in the US.

$\mathrm{H}_{2}$ : Internet dependence will show significant difference based on Age.

$\mathrm{H}_{3}$ : Internet dependence will show significant difference based on Gender.

$\mathrm{H}_{4}$ : Internet dependence will show significant difference based on Race.

\section{LITERATURE REVIEW}

\section{Demographics}

There have been prior manuscripts that have studied Internet use and demographics. These studies have generally produced mixed results. Porter and Donthu [18] studied attitudes towards Internet usage and demographics. They examined the demographic categories of age and race. They found that older individuals have lower perceived ease 
of use . and thus a less positive attitude towards the Internet. Overall though, Porter and Donthu found that attitudes varied significantly based on age but not for race.

Talukdar and Gauri [21] performed a comprehensive study of Home Internet Usage and Socio-economic status in a 2011 study for the Communications of the Association for Information Systems. Their longitudinal study found that a digital divide exists along many socio-economic variables and that it has even widened between 2002 and 2008. They studied income, education, gender, race, age, and residential location. They found significant differences in all these demographic categories in both 2002 and 2008 both in Internet access and daily internet usage. Higher access and usage were found for:

\begin{tabular}{|l|l|}
\hline Male & Same 2002 versus 2008 \\
\hline White Americans & Internet access increased relative to other races \\
\hline Older age & Same \\
\hline
\end{tabular}

Hu, Zhang, Dai, and Zhang [12] used a logistic regression analysis to find gender differences in college students' perception of the internet. They found that males had higher levels of Internet self-efficacy, experience and information overload versus females. Self-efficacy was a measured factor and included statements on proficiency, ease, confidence, and good skills. Experience was measured by hours of use. Information overload was measured by too much information and more information than they could interpret.

Castleton, K., Fong, T., Wang-Gillam, A., Waqar, M. A., Jeffe, D. B., Kehlenbrink, L, Gao \& Govindan, R. [5] performed a detailed demographic analysis of cancer patients who searched the Internet for information about their cancer. They performed chi square analysis based on age, gender, race, and education. They found significant differences in each demographic category except gender. Younger patients $(<59)$ searched the Internet for cancer information more than older patients. Caucasians searched the Internet more than African Americans. And generally more education resulted in more Internet access. There was no significant difference between Males and Females.

Teo [22] studied demographic variables associated with Internet usage activities. He studied gender, age, and educational levels. He found that males were more likely to engage in browsing, downloading activities versus females but messaging activities showed no difference. Age differences depended on specific activity. Older individuals used the Internet more for purchases but younger individuals messaged and downloaded more than older individuals.

van Deursen \& Van Dijk [23] studied a variety of demographic factors and Internet usage in Holland. They used multiple linear regression analysis and studied gender, age, education, income, employment status, and residency. They found significantly greater amount of Internet use for males versus females, less usage for ages 50-64, and higher usage for urban dwellers versus rural. Their findings also reveal some surprising differences than most studies. They found that in the Netherlands lower levels of education lead to higher overall Internet usage (social interaction and gaming). Household income had no significant impact. And disabled individuals showed significantly higher Internet usage. These findings suggest that leisure activities versus information gathering can be significant influences on overall Internet usage and those with more free time or lack of other activities may depend on the Internet more for daily life.

Baturay and Toker [3] found that males engage in cyberloafing to a greater extent than females. Cyberloafing was defined as using the Internet at work for personal purposes.

According to Nie and Ehring [16] "the most important factor facilitating or inhibiting Internet access are education and age, and not income - nor race/ethnicity or gender, each of which account for less than 5 percent change in rates of access and are statistically insignificant.

Joiner, R., Gavin, J., Brosnan, M., Cromby, J., Gregory, H., Guiller, J., ... \& Moon, A. [14] performed a follow up study on gender differences in Internet usage in 2012. Their first study was in 2002 and found that males had a "greater breadth" of Internet use versus females. Their follow up study they found that things had changed with regard to Internet usage. Males still had greater breadth of usage but now found that females use the Internet for communications and social networking more than males. 
Duggan, M., \& Brenner, J. [8] analyzed other Pew survey data and found age, gender, and race play significant roles in social media use with younger individuals, females, and African-Americans showing strong interest in social media.

\begin{tabular}{|l|c|c|c|c|}
\hline \multicolumn{1}{|c|}{ Author } & Year & Age & Gender & Race \\
\hline Porter and Donthu & 2006 & S & & NS \\
\hline Talukdar and Gauri & 2011 & S & S & S \\
\hline Castleton et al. & 2011 & S & NS & \\
\hline Van Deursen et al. & 2014 & S & S & NS \\
\hline Baturay and Toker & 2015 & & NS & S \\
\hline Nie and Ehring & 2000 & S & S & \\
\hline Duggan and Brenner & 2013 & S & & \\
\hline
\end{tabular}

$\mathrm{S}=$ signfifcant, $\mathrm{NS}=$ Not Significant, and Blank=Not tested in this study

A summary of the demographics literature shows that age, when tested, is consistently a significant variable in Internet usage whereas gender and race have shown mixed results.

\section{Internet Addiction and Abuse}

There has also been some studies on the concept of Internet abuse and addiction. According to Christakis and Moreno [7] estimates are that $4 \%$ of Korean children, 15\% of Chinese youth, and 1 in 8 of American adults are addicted to the Internet. The author suggest that all existing behaviors or substances that lead to addiction have social or legal constraints (alcohol, gambling etc.) whereas Internet addiction does not. He suggests there may be a problem that needs to be dealt with.

Brenner [4] also suggests that Internet addiction is a topic that needs to be addressed. Most of users he surveyed suggest that there have been instances where Internet usage has interfered with other aspects of their lives. Chao and Hsiao [6] studied Taiwanese college students and found 54 instances of Internet addiction out of 910 students. They found that males were significantly more likely to the Internet addicts than females. Shin [19] studied Korean and US mobile Internet users. Shin found that Koreans are more "Internet dependent" than US users. He also found that students, unemployed, and younger students are more likely to be Internet dependent. He also found Korean women as being particularly susceptible to Internet dependence. He found no such gender difference in US mobile users. Gencer and Koc [11] studied 1380 high school students in Turkey and found that males were more likely to experience "Internet abuse" than females. Internet abuse was defined by author as "excessive use, ... preoccupation with the Internet, and using the Internet to escape from negative feelings".

Emmanouilides, C., \& Hammond, K. [9] studied predictors of active users and frequency of use and found many reasons for heavier usage but did not study demographics. Amichai-Hamburger, Y., \& Hayat, Z. [1] found that contrary to popular opinion, the Internet does not lead to isolation and loneliness. Rather they found in a study across 13 countries and 22,002 participants that Internet usage can actually enhance social lives of users. Armstrong, L., Phillips, J. G., \& Saling, L. L. [2] studied Internet addiction and its proposed construct derived from DSM-IV which provides a psychological construct for substance abuse. They found that low self-esteem leads to excessive Internet use, They suggest the male, highly educated stereotype of Internet addict be reassessed. LaRose, R., Lin, C. A., \& Eastin, M. S. [15] also examined Internet addiction and found that addiction was not isolated to specific activities but "significantly and positively correlated to Internet across the entire range of consumption". It does however also correlate to depression and habits formed to deal with depression.

\section{RESEARCH METHODOLOGY}

The results in this report are based on data from telephone interviews conducted by Princeton Survey Research Associates International from January 9-12, 2014, among a sample of 1,006 adults, age 18 and older. Telephone interviews were conducted in English and Spanish by landline and cell phone. For results based on the total sample, one can say with $95 \%$ confidence that the error attributable to sampling is plus or minus 3.5 percentage points. For results based on internet users $(\mathrm{N}=857)$, the margin of sampling error is plus or minus 3.9 percentage points. Pew 
Research Center is the source of the data, and the authors acknowledge that the Center bears no responsibility for the interpretations presented or conclusions reached based on analysis of the data. [10] All results were processed using IBM SPSS 22.0.

\section{RESULTS}

\section{Overall}

Before we explore each individual demographic hypothesis, we first must examine whether there is an overall Internet dependence in our overall population. The questions analyzed first then is what are the existence of Internet dependence in the US is today and how strong is this dependence.

$\mathrm{H}_{1}$ : $\quad$ Internet dependence as measured by difficulty of giving up the Internet exists in the US.

Table 1 presents the mean and quartiles for question PIAL5d in the survey. This question will serve as our main dependent variable in this study and reads:

PIAL5 How difficult would it be, if at all, to give up the following things in your life? If you do not use or have the item, just tell me. How hard would it be for you to give up (The internet $1=$ Very Hard, $2=$ Somewhat Hard, $3=$ Not Too Hard, 4=Not Hard at all). [10] There were also some volunteered answers in the study which are noted as VOL. These volunteered answers were not included in any significance analyses.

Table 1 shows that the mean is 1.92 which is more than Somewhat Hard. But Table 2 is the Difficulty Frequency Table and shows that $52.2 \%$ of those surveyed and had valid responses found it Very Hard to Give Up the Internet. A binomial nonparametric test was performed to see if this percentage is statistically significant. We used $50 \%$ as our test proportion and found that $52 \%$ is significantly over half the population at $\mathrm{p}<.024$. There we conclude that Hypothesis 1 is supported. Internet dependence exists in the US and is prevalent in over $50 \%$ of the population.

Table 1. Give Up Internet Statistics

PIAL5d How difficult would it be, if at all, to give up the following things in your life? If you do not use or have the item, just tell me. How hard would it be for you to give up... - The Internet

\begin{tabular}{|c|c|c|}
\hline \multirow[b]{3}{*}{ Mean } & Valid & 2669 \\
\hline & Missing & 413 \\
\hline & & 1.92 \\
\hline \multirow[t]{3}{*}{ Percentiles } & 25 & 1.00 \\
\hline & 50 & 1.00 \\
\hline & 75 & 3.00 \\
\hline
\end{tabular}

Table 2. Difficulty Frequency Table

PIAL5d How difficult would it be, if at all, to give up the following things in your life? If you do not use or have the item, just tell me. How hard would it be for you to give up... - The Internet

\begin{tabular}{|c|c|c|c|c|c|}
\hline & & Frequency & Percent & Valid Percent & Cumulative Percent \\
\hline \multirow[t]{9}{*}{ Valid } & Very hard & 1394 & 45.2 & 52.2 & 52.2 \\
\hline & Somewhat hard & 528 & 17.1 & 19.8 & 72.0 \\
\hline & Not too hard & 398 & 12.9 & 14.9 & 86.9 \\
\hline & Not hard at all & 308 & 10.0 & 11.5 & 98.5 \\
\hline & (VOL.) Impossible & 20 & .6 & .8 & 99.2 \\
\hline & $\begin{array}{l}\text { (VOL.) Do not use / Do not } \\
\text { have }\end{array}$ & 13 & .4 & .5 & 99.7 \\
\hline & (VOL.) Don't know & 5 & .2 & .2 & 99.9 \\
\hline & (VOL.) Refused & 2 & .1 & .1 & 100.0 \\
\hline & Total & 2669 & 86.6 & 100.0 & \\
\hline Missing & System & 413 & 13.4 & & \\
\hline Total & & 3082 & 100.0 & & \\
\hline
\end{tabular}


Table 3. Binomial Test

\begin{tabular}{|c|c|c|c|c|c|}
\hline & Category & $\mathbf{N}$ & Observed Prop. & Test Prop. & $\begin{array}{l}\text { Exact Sig. (2- } \\
\text { tailed) }\end{array}$ \\
\hline $\begin{array}{ll}\text { PIAL5d How difficult would it } & \text { Group 1 } \\
\text { be, if at all, to give up the } & \text { Group 2 } \\
\text { following things in your life? If } & \text { Total } \\
\text { you do not use or have the item, } & \\
\text { just tell me. How hard would it } & \\
\text { be for you to give up... - The } & \\
\text { Internet } & \end{array}$ & $\begin{array}{l}<=1 \\
>1\end{array}$ & $\begin{array}{l}1412 \\
1294 \\
2706\end{array}$ & $\begin{array}{l}.52 \\
.48 \\
\\
1.00\end{array}$ & .50 & .024 \\
\hline
\end{tabular}

\section{Age}

Today's youth and young adults have grown up with the Internet. They have been immersed in its content to varying degrees but many have been online since shortly after birth. Familiarity and acceptance of the Internet would lead one to believe that the younger the person, the more they would be reliant and dependent of the Internet as a primary information sources. Our second hypothesis tests the proposition that there will be significant difference in Internet dependence based on age. As noted, most studies have found that older individuals are less Internet dependent. Our results concur with prior studies. In general, age is a significant independent variable influencing Internet dependence. Table 4 shows a regression analysis based on actual age and increasing age adds to less Internet dependency (Internet dependency is reverse scaled with higher dependency represented by a lower value).

Table 5 The Internet * AgeRange Crosstabulation shows percentages of dependence by age range. A full $78 \%$ of 18 25 year olds would find giving up the Internet Very Hard. A chi-square analysis shows differences in groups significant at $\mathrm{p}<.001 . \mathrm{H}_{2}$ : Internet dependence will show significant difference based on Age was supported.

Table 4. Age Coefficients ${ }^{\mathrm{a}}$

\begin{tabular}{|c|l|l|l|l|l|}
\hline \multirow{2}{*}{\multicolumn{2}{|c|}{ Model }} & \multicolumn{2}{|c|}{ Unstandardized Coefficients } & \multicolumn{1}{c|}{$\begin{array}{c}\text { Standardized } \\
\text { Coefficients }\end{array}$} & \multirow{2}{*}{ Sig. } \\
\cline { 2 - 5 } & \multicolumn{2}{|c|}{ B } & Std. Error & Beta & \\
\hline 1 & 1.607 & .059 & & 27.257 & .000 \\
& (Constant) & .001 & .110 & 5.717 & .000 \\
\hline
\end{tabular}

a. Dependent Variable: PIAL5d How difficult would it be, if at all, to give up the following things in your life? If you do not use or have the item, just tell me. How hard would it be for you to give up... - The Internet

Table 5. The Internet* AgeRange Crosstabulation

PIAL5d How difficult would it be, if at all, to give up the following things in your life? If you do not use or have the item, just tell me. How hard would it be for you to give up...-

\begin{tabular}{|c|c|c|c|c|c|c|c|c|c|}
\hline & \multicolumn{6}{|c|}{ AgeRange } & \multirow[b]{2}{*}{ Total } \\
\hline & & & $18-25$ & $26-35$ & $36-45$ & $46-55$ & $56-65$ & Over 65 & \\
\hline \multirow{8}{*}{$\begin{array}{l}\text { PIAL5d How } \\
\text { difficult would it } \\
\text { be, if at all, to give } \\
\text { up the following } \\
\text { things in your life? } \\
\text { If you do not use or } \\
\text { have the item, just } \\
\text { tell me. How hard } \\
\text { would it be for you } \\
\text { to give up... - The } \\
\text { Internet }\end{array}$} & \multirow[t]{2}{*}{ Very hard } & Count & 51 & 48 & 72 & 72 & 90 & 75 & 408 \\
\hline & & {$\left[\begin{array}{l}\% \text { within } \\
\text { AgeRange }\end{array}\right.$} & $78.5 \%$ & $72.7 \%$ & $66.1 \%$ & $47.1 \%$ & $56.6 \%$ & $45.5 \%$ & $56.9 \%$ \\
\hline & \multirow{2}{*}{ Somewhat hard } & Count & 10 & 11 & 29 & 35 & 23 & 40 & 148 \\
\hline & & $\mid \begin{array}{l}\% \text { within } \\
\text { AgeRange }\end{array}$ & $15.4 \%$ & $16.7 \%$ & $26.6 \%$ & $22.9 \%$ & $14.5 \%$ & $24.2 \%$ & $20.6 \%$ \\
\hline & \multirow[t]{2}{*}{ Not too hard } & Count & 4 & 0 & 2 & 23 & 24 & 38 & 91 \\
\hline & & $\mid \begin{array}{l}\% \text { within } \\
\text { AgeRange }\end{array}$ & $6.2 \%$ & $0.0 \%$ & $1.8 \%$ & $15.0 \%$ & $15.1 \%$ & $23.0 \%$ & $12.7 \%$ \\
\hline & \multirow[t]{2}{*}{ Not hard at all } & Count & 0 & 7 & 6 & 23 & 18 & 9 & 63 \\
\hline & & {$\left[\begin{array}{l}\% \text { within } \\
\text { AgeRange }\end{array}\right.$} & $0.0 \%$ & $10.6 \%$ & $5.5 \%$ & $15.0 \%$ & $11.3 \%$ & $5.5 \%$ & $8.8 \%$ \\
\hline
\end{tabular}




\begin{tabular}{|c|c|c|c|c|c|c|c|c|c|}
\hline & (VOL.) Impossible & $\begin{array}{l}\text { Count } \\
\% \text { within } \\
\text { AgeRange }\end{array}$ & $\mid \begin{array}{l}0 \\
0.0 \%\end{array}$ & $\mid \begin{array}{l}0 \\
0.0 \%\end{array}$ & $\mid \begin{array}{l}0 \\
0.0 \%\end{array}$ & $\mid \begin{array}{l}0 \\
0.0 \%\end{array}$ & $2.5 \%$ & $\mid \begin{array}{l}1 \\
0.6 \%\end{array}$ & 5 \\
\hline & $\begin{array}{l}\text { (VOL.) Do not use } \\
\text { Do not have }\end{array}$ & $\begin{array}{l}\text { Count } \\
\% \text { within } \\
\text { AgeRange }\end{array}$ & $\begin{array}{l}0 \\
0.0 \%\end{array}$ & $\begin{array}{l}0 \\
0.0 \%\end{array}$ & $\begin{array}{l}0 \\
0.0 \%\end{array}$ & $\begin{array}{l}0 \\
0.0 \%\end{array}$ & $\begin{array}{l}0 \\
0.0 \%\end{array}$ & 2 & 2 \\
\hline Total & & $\begin{array}{l}\text { Count } \\
\% \text { within } \\
\text { AgeRange }\end{array}$ & $\begin{array}{l}65 \\
100.0 \%\end{array}$ & $\begin{array}{l}66 \\
100.0 \%\end{array}$ & $\begin{array}{l}109 \\
100.0 \%\end{array}$ & $\begin{array}{l}153 \\
100.0 \%\end{array}$ & $\begin{array}{l}159 \\
100.0 \%\end{array}$ & $\begin{array}{l}165 \\
100.0 \%\end{array}$ & $\begin{array}{l}717 \\
100.0 \%\end{array}$ \\
\hline
\end{tabular}

\section{Gender}

As noted in the literature review, prior studies have shown mixed results with regard to gender and Internet usage. Our study found clear support that females have greater dependency on the Internet. Regression analysis (table 6) shows significance at $\mathrm{p}<.001$. Table 7 presents that $56 \%$ of females versus $48 \%$ of males would find it Very Hard to give up the Internet and a subsequent Chi-square analysis is significant at $\mathrm{p}<.001 . \mathrm{H}_{3}$ : Internet dependence will show significant difference based on Gender was supported.

Table 6. Gender Coefficients ${ }^{\mathrm{a}}$

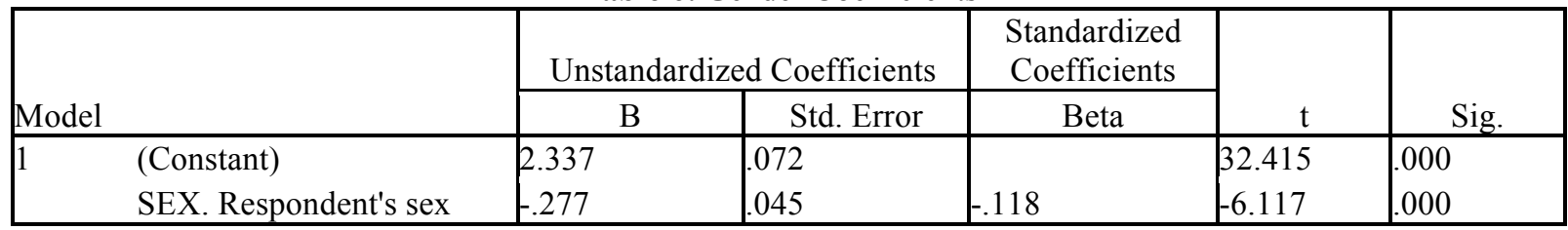

a. Dependent Variable: PIAL5d How difficult would it be, if at all, to give up the following things in your life? If you do not use or have the item, just tell me. How hard would it be for you to give up... - The Internet

Table 7. The Internet* SEX. Respondent's sex Crosstabulation

PIAL5d How difficult would it be, if at all, to give up the following things in your life? If you do not use or have the item, just tell me. How hard would it be for you to give up...-

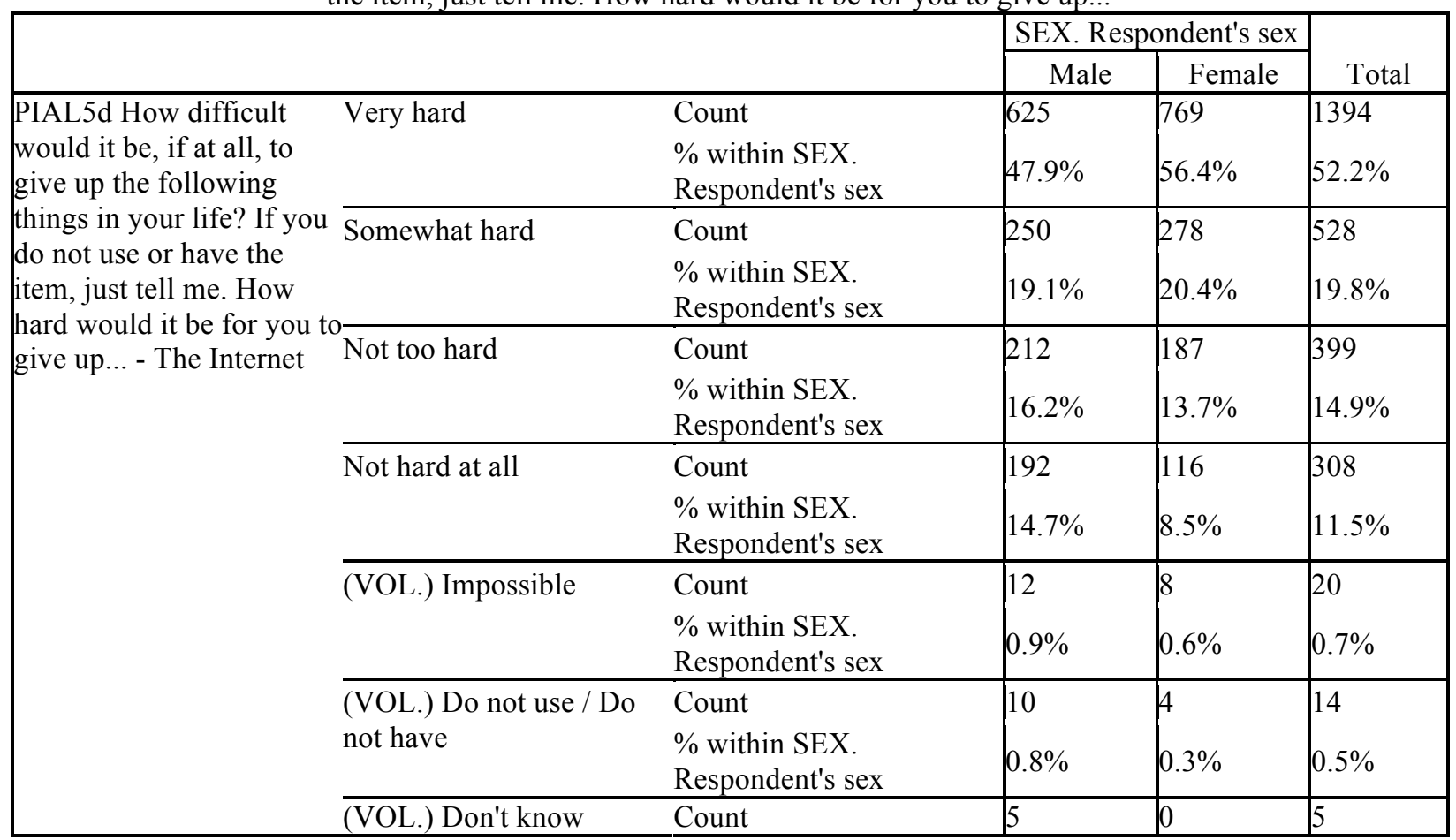




\begin{tabular}{|c|c|c|c|c|c|}
\hline \multirow[b]{3}{*}{ Total } & & $\begin{array}{l}\% \text { within SEX. } \\
\text { Respondent's sex }\end{array}$ & $0.4 \%$ & $0.0 \%$ & $0.2 \%$ \\
\hline & \multirow[t]{2}{*}{ (VOL.) Refused } & $\begin{array}{l}\text { Count } \\
\% \text { within SEX. } \\
\text { Respondent's sex }\end{array}$ & 0 & 2 & 2 \\
\hline & & $\begin{array}{l}\text { Count } \\
\% \text { within SEX. } \\
\text { Respondent's sex }\end{array}$ & $\begin{array}{l}1306 \\
100.0 \%\end{array}$ & $\begin{array}{l}1364 \\
100.0 \%\end{array}$ & $\begin{array}{l}2670 \\
100.0 \%\end{array}$ \\
\hline
\end{tabular}

\section{RACE}

Another area where researchers have differed is whether Internet usage varies by race. Our study found a clear difference for Internet dependence and race. Table 8 shows that only $51 \%$ of Whites found giving up the Internet Very Hard but that figure rises to $55 \%$ for Blacks or African-Americans and $77 \%$ for Asian or Pacific Islanders. These differences were significant tested via Chi-square analysis at $\mathrm{p}<.001 . \mathrm{H}_{4}$ : Internet dependence will show significant difference based on Race was supported.

Table 8. What is Your Race? Are You White, Black, Asian, or Some Other Race? Crosstabulation PIAL5d How difficult would it be, if at all, to give up the following things in your life? If you do not use or have the item, just tell me. How hard would it be for you to give up... - The Internet* RACE

\begin{tabular}{|c|c|c|c|c|c|c|c|c|c|}
\hline & \multicolumn{7}{|c|}{ RACE. What is your race? Are you white, black, Asian, or some other race? } & \multirow[b]{2}{*}{ Total } \\
\hline & & White & $\begin{array}{l}\text { Black or } \\
\text { African- } \\
\text { American }\end{array}$ & $\begin{array}{l}\text { Asian or } \\
\text { Pacific } \\
\text { Islander }\end{array}$ & $\begin{array}{c}\text { Mixed } \\
\text { race }\end{array}$ & $\begin{array}{c}\text { Native } \\
\text { American/Americ } \\
\text { an Indian }\end{array}$ & $\begin{array}{c}\text { Other } \\
\text { (SPECIFY) }\end{array}$ & $\begin{array}{c}\text { Don't } \\
\text { know/Refused } \\
\text { (VOL.) }\end{array}$ & \\
\hline \multirow[t]{2}{*}{ Very hard } & Count & 1025 & 183 & 95 & 28 & 20 & 16 & 26 & 1393 \\
\hline & $\%$. & $50.7 \%$ & $55.0 \%$ & $77.2 \%$ & $73.7 \%$ & $50.0 \%$ & $31.4 \%$ & $41.3 \%$ & $52.2 \%$ \\
\hline \multirow{2}{*}{$\begin{array}{l}\text { Somewhat } \\
\text { hard }\end{array}$} & Count & 431 & 54 & 9 & 10 & 7 & 7 & 10 & 528 \\
\hline & $\%$ & $21.3 \%$ & $16.2 \%$ & $7.3 \%$ & $26.3 \%$ & $17.5 \%$ & $13.7 \%$ & $15.9 \%$ & $19.8 \%$ \\
\hline \multirow{2}{*}{$\begin{array}{l}\text { Not too } \\
\text { hard }\end{array}$} & Count & 299 & 48 & 15 & 0 & 7 & 25 & 4 & 398 \\
\hline & $\%$ & $14.8 \%$ & $14.4 \%$ & $12.2 \%$ & $0.0 \%$ & $17.5 \%$ & $49.0 \%$ & $6.3 \%$ & $14.9 \%$ \\
\hline \multirow{2}{*}{$\begin{array}{l}\text { Not hard at } \\
\text { all }\end{array}$} & Count & 236 & 48 & 4 & 0 & 6 & 3 & 12 & 309 \\
\hline & $\%$ & $11.7 \%$ & $14.4 \%$ & $3.3 \%$ & $0.0 \%$ & $15.0 \%$ & $5.9 \%$ & $19.0 \%$ & $11.6 \%$ \\
\hline \multirow{2}{*}{\begin{tabular}{|l} 
VOL.) \\
Impossible \\
\end{tabular}} & Count & 20 & 0 & 0 & 0 & 0 & 0 & 0 & 20 \\
\hline & $\%$ & $1.0 \%$ & $0.0 \%$ & $0.0 \%$ & $0.0 \%$ & $0.0 \%$ & $0.0 \%$ & $0.0 \%$ & $0.7 \%$ \\
\hline \multirow{2}{*}{$\begin{array}{l}\text { (VOL.) Do } \\
\text { not use / } \\
\text { Do not } \\
\text { have }\end{array}$} & Count & 10 & 0 & 0 & 0 & 0 & 0 & 4 & 14 \\
\hline & $\%$ & $0.5 \%$ & $0.0 \%$ & $0.0 \%$ & $0.0 \%$ & $0.0 \%$ & $0.0 \%$ & $6.3 \%$ & $0.5 \%$ \\
\hline \multirow{2}{*}{$\begin{array}{l}\text { (VOL.) } \\
\text { Don't know }\end{array}$} & Count & 0 & 0 & 0 & 0 & 0 & 0 & 5 & 5 \\
\hline & $\%$ & $0.0 \%$ & $0.0 \%$ & $0.0 \%$ & $0.0 \%$ & $0.0 \%$ & $0.0 \%$ & $7.9 \%$ & $0.2 \%$ \\
\hline \multirow{2}{*}{\begin{tabular}{|l} 
(VOL.) \\
Refused
\end{tabular}} & Count & 0 & 0 & 0 & 0 & 0 & 0 & 2 & 2 \\
\hline & $\%$ & $0.0 \%$ & $0.0 \%$ & $0.0 \%$ & $0.0 \%$ & $0.0 \%$ & $0.0 \%$ & $3.2 \%$ & $0.1 \%$ \\
\hline \multirow[t]{2}{*}{ Total } & Count & 2021 & 333 & 123 & 38 & 40 & 51 & 63 & 2669 \\
\hline & $\%$ & $100.0 \%$ & $100.0 \%$ & $100.0 \%$ & $100.0 \%$ & $100.0 \%$ & $100.0 \%$ & $100.0 \%$ & $100.0 \%$ \\
\hline
\end{tabular}

\section{CONCLUSIONS}

Unlike many prior studies, our report analyzes a detailed and scientific sample cross section of the US population based on the Pew Internet survey. Our results found that Internet dependence appears to be a real phenomenon with over $50 \%$ of the population finding it Very Hard to give up the Internet. This rate rises when age is factored into the equation. Fully $78 \%$ of $18-25$ year olds would find it Very Hard to give up the Internet. With regard to hypotheses, Age, Gender and Race were found to be significant variables influencing Internet dependence. Younger Americans, 
females, and Asian and African Americans were found to be more dependent. Whether this is a problem or just a harmless support activity for Americans was not within the scope of this study but this high dependence and demographic profile presents important information for researchers and practitioners. Further study is recommended to determine whether these recognized dependencies are a threat or a boon. The demographic analyses can then be used to target potential behavioral modification efforts. A limitation of the study is that it deals only with selfresponses, and not actual observation though little bias is expected due to sample methodology and anonymity. Another limitation is the number of demographic variables studied. Other variables such as race, community type, and education level and interactive effects of these demographic variables will be studied in future work.

\section{REFERENCES}

1. Amichai-Hamburger, Y., \& Hayat, Z. (2011). The impact of the Internet on the social lives of users: A representative sample from 13 countries. Computers in Human Behavior, 27(1), 585-589.

2. Armstrong, L., Phillips, J. G., \& Saling, L. L. (2000). Potential determinants of heavier internet usage. International Journal of Human-Computer Studies, 53(4), 537-550.

3. Baturay, M. H., \& Toker, S. (2015). An investigation of the impact of demographics on cyberloafing from an educational setting angle. Computers in Human Behavior, 50, 358-366.

4. Brenner, V. (1997). Psychology of computer use: XLVII. Parameters of Internet use, abuse and addiction: the first 90 days of the Internet Usage Survey. Psychological reports, 80(3), 879-882.

5. Castleton, K., Fong, T., Wang-Gillam, A., Waqar, M. A., Jeffe, D. B., Kehlenbrink, L, Gao, F. \& Govindan, R. (2011). A survey of Internet utilization among patients with cancer. Supportive Care in Cancer, 19(8), 11831190.

6. Chou, C., \& Hsiao, M. C. (2000). Internet addiction, usage, gratification, and pleasure experience: the Taiwan college students' case. Computers \& Education, 35(1), 65-80.

7. Christakis, D. A., \& Moreno, M. A. (2009). Trapped in the net: will internet addiction become a 21 st-century epidemic?. Archives of pediatrics \& adolescent medicine, 163(10), 959-960.

8. Duggan, M., \& Brenner, J. (2013). The demographics of social media users, 2012 (Vol. 14). Washington, DC: Pew Research Center's Internet \& American Life Project.

9. Emmanouilides, C., \& Hammond, K. (2000). Internet usage: Predictors of active users and frequency of use. Journal of Interactive Marketing, 14(2), 17-32.

10. Fox, S. and Raine. (2014) The Web at 25 in the U.S. http://www.pewinternet.org/2014/02/27/the-web-at-25-inthe-u-s

11. Gencer, S. L., \& Koc, M. (2012). Internet Abuse among Teenagers and Its Relations to Internet Usage Patterns and Demographics. Educational Technology \& Society, 15(2), 25-36.

12. Hu, T., Zhang, X., Dai, H., \& Zhang, P. (2012). An examination of gender differences among college students in their usage perceptions of the internet. Education and Information Technologies, 17(3), 315-330.

13. Internet World Stats (2015). http://www.internetworldstats.com/stats.htm

14. Joiner, R., Gavin, J., Brosnan, M., Cromby, J., Gregory, H., Guiller, J., ... \& Moon, A. (2012). Gender, internet experience, internet identification, and internet anxiety: a ten-year followup. Cyberpsychology, Behavior, and Social Networking, 15(7), 370-372.

15. LaRose, R., Lin, C. A., \& Eastin, M. S. (2003). Unregulated Internet usage: Addiction, habit, or deficient selfregulation?. Media Psychology, 5(3), 225-253.

16. Nie, N. H., \& Erbring, L. (2000). Internet and society. Stanford Institute for the Quantitative Study of Society.

17. Park, C., \& Jun, J. K. (2003). A cross-cultural comparison of Internet buying behavior: Effects of Internet usage, perceived risks, and innovativeness. International Marketing Review, 20(5), 534-553.

18. Porter, C. E., \& Donthu, N. (2006). Using the technology acceptance model to explain how attitudes determine Internet usage: The role of perceived access barriers and demographics. Journal of business research, 59(9), 999-1007.

19. Shin, L. Y. (2014). A Comparative Study of Mobile Internet Usage between the US and Korea. Journal of European Psychology Students, 5(3), 46-55.

20. Statistical Abstract of the United States (2012). http://www.census.gov/compendia/statab/2012/tables/12s1240.pdf 


\section{Issues in Information Systems \\ Volume 16, Issue II, pp. 176-184, 2015}

21. Talukdar, D., \& Gauri, D. K. (2011). Home internet access and usage in the USA: trends in the socio-economic digital divide. Communications of the Association for Information Systems, 28(7), 85-98.

22. Teo, T. S. (2001). Demographic and motivation variables associated with Internet usage activities. Internet Research, 11(2), 125-137.

23. van Deursen, A. J., \& Van Dijk, J. A. (2014). The digital divide shifts to differences in usage. New Media \& Society, 16(3), 507-526. 